\author{
Maria Szczepska-Pustkowska \\ Uniwersytet Gdański \\ maja.pustkowska@gmail.com
}

\title{
Dziecięce filozofowanie na tle romantycznej wizji szlachetnego dzikusa J.J. Rousseau
}

\section{Summary \\ Children philosophizing against the background of the romantic vision of the noble savage by J.J. Rousseau}

The $18^{\text {th }}$ century brought a sequence of outlook changes to Europe. Although contemporary transformations occurred slowly, their scale exceeded the previously circumscribed frame. Interpenetration of various ideas and cultural achievements, as well as "transnational exchange", supported information for the coming into existence of the first theories of childhood. One of such theories was born thanks to Jean Jacques Rousseau (1712-1778), thanks to which the Enlightenment and the Romanticism discovered the noble savage child immersed in nature. Reflection on the phenomenon of childlike philosophizing conducted exactly from the perspective of this romantic vision of the child is the purpose of this paper.

Słowa kluczowe: J.J. Rousseau, wizja szlachetnego dzikusa, fenomen dziecięcego filozofowania

Keywords J.J. Rousseau, noble savage child, the phenomenon of childlike philosophizing

Wiek XVIII przyniósł Europie szereg zmian światopoglądowych. Chociaż ówczesne przemiany zachodziły powoli, jednak ich skala przekroczyła dotychczasowo zakreślone ramy. Wzajemne przenikanie się rozmaitych idei i osiągnieć kulturowych oraz „międzynarodowa wymiana" informacji sprzyjały również powstaniu pierwszych teorii dzieciństwa. Jedna z takich teorii zrodziła się za sprawą Jeana Jacquesa Rousseau (1712-1778), dzięki któremu oświecenie i panujący w nim romantyzm odkryły w dziecku szlachetnego dzikusa zanurzonego w przyrodzie. Celem niniejszego artykułu jest refleksja nad fenomenem dziecięcego filozofowania prowadzona właśnie z perspektywy tej romantycznej wizji dziecka.

\section{Człowiek urodzil się wolnym, a wszędzie jest w okowach}

W oświeceniu, które gloryfikowało postęp, pojawił się głos weń wątpiący. W jego miejsce J.J. Rousseau zaproponował prostotę, naturę, stan pierwotny i człowieka dzikiego jako

1 Rousseau J.J. (2010), Umowa społeczna. Warszawa, Wydawnictwo Naukowe PWN, s. 11. 
wzór w budowaniu społeczeństwa i edukacji. Głos Rousseau nie był co prawda w tej materii ani pierwszy, ani jedyny. Zarówno wczesne utopie (Thomasa Moore'a czy Tommaso Campanelli), jak również utopie nieco późniejsze (Gabriela Foigny, Claude’a Gilberta czy Françoisa Fénelona) dokonywały już krytyki ówczesnego społeczeństwa europejskiego, wytykając słabości jego kultury. Odwołując się do wyników ówczesnych badań etnograficznych, także one propagowały prostotę, równość oraz życie zgodne z naturą (por. Orłowski 1921). Zapewne niektóre z tych studiów znał również Rousseau.

Wizerunek człowieka żyjącego w ,stanie natury” J.J. Rousseau przedstawił w Rozprawie o pochodzeniu i podstawach nierówności między ludźmi (1755), czyniąc go podstawą swojej filozofii politycznej i opisu początków organizacji społecznej. Filozof przedstawił w niej model stanu natury poprzedzający organizację społeczną; śledził hipotetyczny rozwój człowieka od stadium naturalnego (dzikiego) aż po współczesny mu świat cywilizacji europejskiej osiemnastego stulecia. Ten mityczny stan pierwotny Rousseau wyobrażał sobie jako czas, w którym ludzie żyli w przyrodzie i zjednoczeni przyrodą, wykazując wobec siebie sympatię. Człowiek dziki był wolny w pełnym tego słowa znaczeniu (bowiem w stanie natury żył samotnie i na własny rachunek), a różnice między ludźmi były dużo mniejsze niż w warunkach cywilizacji, co miało wynikać z jednostajności i prostoty ich życia oraz braku więzów i nierówności o charakterze instytucjonalnym. Opuszczenie przez szlachetnego dzikusa owego pierwotnego niewinnego stanu natury na rzecz cywilizacji i kultury stało się, zdaniem Rousseau, początkiem problemów ludzkości (por. Rousseau 1954).

Zasadniczy wątek w myśli Rousseau wynika z przeciwstawienia tego, co bezpośrednie, pierwotne, zakończone, całkowite, wolne i proste temu, co pochodne, względne, podzielne, zależne i złożone, a zatem bezwzględnego samorozwoju życia (opartego na własnej wewnętrznej sile i własnym wewnętrznym nacisku), ograniczeniu, przymusowi, podzielności i rozdrobnieniu (mającym swoje źródło w zewnętrznych stosunkach, od których życie ludzi jest zależne). Przeciwstawienie rzeczy bezwzględnych i względnych stanowi sedno kontrastu między naturą i kulturą (Höffding 1900: 74-75).

Wprawdzie termin natura w dziełach Rousseau nie jest wyraźnie określony, jednak w jego tekstach można odnaleźć trzy znaczenia tego terminu, które filozof wyprowadzał z trzech odrębnych porządków: teologicznego, przyrodniczo-historycznego i psychologicznego (Peretiatkowicz 1949: 39)².

Teologiczne ujęcie natury stosował tam, gdzie prostotę i naturę ujmował jako pierwotne dzieło Boga. Przeciwstawiał je ,zniekształceniom” i ,zwyrodnieniom”, do których doprowadzili ludzie. Pisał z żalem, iż nie odnajduje już w człowieku boskiej prostoty, którą obdarzył go Stwórca. Dowodził, że wszystko jest dobrem dopóty, dopóki pozostaje

\footnotetext{
2 [Rousseau, pisząc w pierwszych swych dziełach o naturze, miał na myśli głównie stan natury. W dziełach późniejszych (między innymi w Emilu) mówił natomiast o naturalnym człowieku w stanie społecznym i kulturze naturalnej, odpowiadającej ogólnym warunkom życia. W kolejnych rozprawach Rousseau przyjął, iż naturę człowieka, ze względów społecznych, należy poddać modyfikacjom przez odpowiednie wychowanie socjalne. W swoich ostatnich pracach pojęcie natury porzucił całkowicie].
} 
takim, jakim wyszło z rąk Stwórcy. Wreszcie - wolę boską przeciwstawiał sztuce ludzkiej (Höffding 1900: 75).

Przyrodniczo-historyczne ujęcie natury zostało wykorzystane przez Rousseau w sposób najbardziej wyrazisty we wspomnianej rozprawie o nierówności, w której autor dokonał wnikliwego opisu stanu pierwotnego (por. Rousseau 1954). Filozof nie brał tu pod uwagę ani supranaturalnego uposażenia człowieka, ani też jego „sztucznych” ulepszeń, powstałych pod wpływem kultury. Chociaż zatem pierwotny stan teologiczny i przyrodniczo-historyczny bardzo różnią się od siebie już na poziomie genezy i pochodzenia, to łączy je fakt, że oba swoim istnieniem wyprzedzają wszelką kulturę (Höffding 1900: 76).

Psychologiczne pojęcie natury, do którego Rousseau odwołuje się najczęściej, zostało natomiast wyprowadzone drogą samoobserwacji, w której filozof pominął zarówno ponadnaturalne działanie Boga, jak i historię naturalną. Uwagę swoją filozof skoncentrował na tym, co dzieje się w duszy ludzkiej i w ten sposób starał się odnaleźć i wskazać zasadnicze siły ludzkiej istoty. Dostrzegał, że to, co decyduje o owej istocie, obecne jest w różnym stopniu we wszystkich okresach czasu człowieka - przeszłości, teraźniejszości i przyszłości. Stanem naturalnym jest zatem taki stan, w którym wszystkie zasadnicze składowe owej istoty uzyskują w pełni dojrzałą postać. Jednocześnie jednak filozof zastrzegał, że jest to stan, który nigdy nie istniał i prawdopodobnie istnieć nie będzie, lecz który należy sobie wyobrazić po to, by zyskać możliwość oceny stanu obecnego. Ta psychologiczna teza została zatem użyta przez Rousseau jako swoista skala porównawcza. Gdy pisał, że człowiek z natury jest dobry, wskazywał, że zasadnicze skłonności człowieka są dobre, że jego „rdzeń” jest dobry. Zalecał, by ludzie, zamiast koncentrować się na „ofertach” świata zewnętrznego, zwrócili się w głąb siebie - do własnych serc, i w głębi swojej istoty starali się odnaleźć źródło wszelkiej dobroci i szczęścia (tamże: 76-77).

Człowieka, jak sądził, najlepiej charakteryzuje popęd samozachowawczy i dążenie do wszechstronnego rozwoju. Ten popęd określał mianem miłości ku własnej istocie (amour de soi). Przeciwstawiał jej miłość własną (amour propre), która powstaje dopiero w społeczeństwie (jako wynik porównania siebie z innymi). Przejawia się ona pragnieniem uzyskania przewagi nad innymi, oczekiwaniem zaszczytów, poszukiwaniem ich dla własnych korzyści. Kiedy człowiek żyje jedynie sam ze sobą (jako jednostka odosobniona), uczucie miłości własnej i towarzyszący mu egoizm po prostu nie istnieją, ponieważ nie istnieją okoliczności społeczne sprzyjające ich powstaniu. Opozycja miłości ku własnej istocie i miłości własnej pojawia się dopiero tam, gdzie działa społeczeństwo. To właśnie ona odpowiada za przeciwstawienie natury kulturze. Siła tkwiąca w miłości ku istocie własnej „przelewa” się na inne przedmioty, o ile są one do nas podobne. W ten sposób powstają: miłość (do innych), litość, dobroć i inne uczucia, będące następstwem rozszerzania własnego ja i miłości siebie samego. Na tym podłożu rodzi się również sumienie, a więc miłość tego, co dobre i nienawiść ku temu, co złe. Kiedy jednak w życiu jednostki zaczynają dominować siły zewnętrzne, co jest nieuniknionym następstwem życia społecznego, rodzi się miłość własna, która opiera się na porównaniu do innych i która przybiera różne formy - od ambicji i próżności, przez chciwość i zazdrość po zemstę. Ten rodzaj miłości, 
zdaniem Rousseau, nigdy nie zostaje zaspokojony, gdyż popycha on człowieka do tego, by stawiał się ponad innymi oraz by inni traktowali go w ten sam sposób (tamże: 77-78).

W konsekwencji przejście od natury ku kulturze, powodujące upadek i będące przeszkodą dla osiągnięcia harmonijnego bytu, zasadza się na przejściu od absolutnego istnienia (zawartego w samym sobie), do istnienia względnego, zależnego (od zewnętrznego świata).

Wydaje się, że natura jest dla Rousseau pomocniczym pojęciem etycznym, które syntetyzuje jego ideał społeczno-moralny (Peretiatkowicz 1949: 57-58). Posiada ona zatem charakter realistyczno-normatywny; odnosi się do hipotetycznej przeszłości historycznej $\mathrm{z}$ jednej strony, z drugiej zaś - tworzy normę(y) postępowania.

Rousseau, pisząc o kulturze i człowieku kultury, miał na uwadze głównie kulturowe cechy cywilizacji europejskiej (por. Golka 2012: 397-398). Wśród podstawowych zarzutów kierowanych pod jej adresem wskazywał: służebność wobec władzy klasy panującej (Rousseau 1956: 11), ukrywanie ludzkich ułomności, (z)niszczenie prostoty, wyzbycie się naturalności, bezpośredniości w komunikowaniu się ludzi, uniformizację (przede wszystkim w dziedzinie obyczajów), postępowanie zgodnie ze zwyczajami (cechami nabytymi), a nie z naturą (cechami wrodzonymi), zgubne wypaczenie kardynalnych cnót człowieka (prostoty, niewiedzy, wojowniczości, patriotyzmu). Rousseau uważał także, że wszelkie wytwory cywilizacji (w tym nauka i sztuka) powstają wskutek występków (niesprawiedliwości, próżności i agresji) i przyczyniają się do występków (zbytku, rozprzężenia i zniewolenia) (Golka 2012: 3-46). Oskarżał cywilizację o niewolenie człowieka przez pobudzanie w nim sztucznych potrzeb, do zaspokojenia których niezbędne jest działanie wielu osób, co prowadzi do podwójnego uzależnienia jednostki (od owych potrzeb i od innych), przez co traci ona swoją pierwotną niezależność (Branowska 2013: 59).

Dowodził, że powstanie społeczeństwa jest początkiem wszelkiego ucisku i nierówności (łączył to z rozwojem rozumu, który miał niszczyć i tłumić naturalną skłonność człowieka do współczucia), choć był równocześnie przekonany, że społeczeństwo mogłoby być zorganizowane w inny sposób, gdyby ludzie dostrzegli korzyści, które płyną ze wzajemnej współpracy i dobrowolnie zrezygnowali z praw naturalnych, poddając się powszechnej woli społeczeństwa. Tę zaś postrzegał nie jako sumę pragnień jednostek, lecz jako coś, co wyraża interes całego społeczeństwa i przynosi powszechne dobro (Rousseau 2010: 34-35). Wskazywał, że w tak rozumianym społeczeństwie wolność nie polega na tym, iż każdy ma prawo robić to, na co ma ochotę. Zaspokojenie pragnień nie jest bowiem wolnością, lecz raczej jednym z rodzajów zniewolenia przez namiętności. Prawdziwa wolność zatem polega na życiu w zgodzie z regułami społecznymi, wyrażonymi w woli powszechnej. Jeśli więc człowiek nie potrafi się poddać tej powszechnej woli, może zostać „przymuszony do wolności”, gdyż wola powszechna oddaje to, czego naprawdę pragnie, nawet jeśli nie jest tego świadomy (tamże).

Chociaż J.J. Rousseau nakreślił wyidealizowany obraz człowieka pierwotnego, którego postrzegał jako istotę czystą i nieskażoną cywilizacją (obdarzoną cechami hojności i bezinteresowności, niewinności, niezdolności do kłamstwa, wierności, zdrowiem fizycznym, gotowością do wyparcia się dóbr doczesnych, odwagą moralną, ,naturalną” 
inteligencją i wrodzoną, niewyuczoną mądrością), to w swoich dziełach nigdy nie użył określenia „szlachetny/ dobry dzikus”, które w jego czasach stawiane było jako punkt odniesienia wobec ówczesnej cywilizacji europejskiej. Tworząc wizerunek człowieka, pisał o nim jako o kimś żyjącym w „stanie natury”, obstając przy tym, że człowiek rodzi się jako potencjalnie dobry, a dopiero cywilizacja czyni go złym, co uwydatnił w stwierdzeniu: „(w)szystko wychodząc z rąk Stwórcy jest dobre, wszystko wyrodnieje w rękach człowieka" (Rousseau: 1955: 7).

\section{Emil, czyli o wychowaniu - rekonstrukcja głównych idei}

Przekonanie Rousseau, że kultura i społeczeństwo mają zły wpływ na jednostkę, stało się ważną częścią wypracowanej przez niego teorii edukacji, której istotę wyłożył w wydanym w 1762 r. Emilu czyli o wychowaniu (Bloom 1979: 28)3. Zdaniem samego Rousseau dzieło to nie jest jednak tylko rozprawą pedagogiczną; autor nie uważał go jedynie za praktyczny traktat o wychowaniu, lecz jako kontynuację swojej filozofii. W Emilu kluczową rolę odegrały dwie tezy, że: człowiek jest dobry z natury oraz, że źli sa wyłacznie konkretni ludzie. Rousseau ,usiłuje w niej pogodzić wiarę w to, że człowiek z natury swej jest dobrym, z jego, przez doświadczenie stwierdzoną, złośliwością. (...) usiłuje wykazać, iż wszystkie występki stają się zrozumiałemi, gdy bada się historyę serca ludzkiego, system zaś wychowawczy, przedstawiony w książce, służy tylko za ramę dla tej idei” (Höffding 1900: 66-67).

Skoro zatem dziecko rodzi się wyłącznie z dobrymi skłonnościami, to siłą rzeczy jego złe cechy rozwijają się dopiero później. Przyczyn tego „wyrodnienia” upatrywał Rousseau w kulturze i niewłaściwym wychowaniu. Rezygnując z powszechnie podzielanego poglądu o naturalnej złośliwości dziecka i wskazując, że każde dziecko jest z gruntu dobre, wyjaśniał, że wychowanie nie może opierać się na represji. Dowodził, że dziecko należy wychowywać zgodnie z wrodzonymi skłonnościami, a więc zgodne z jego dobrą naturą.

Swoje rozważania o wychowaniu Rousseau otwiera zarzutem, że nie znamy natury dziecka i wieku dziecięcego. Ich znajomość zdaje się mieć dla niego większe znaczenie, niż prezentowana przezeń metoda. Filozof zaznacza, że najważniejszym momentem wychowawczym jest ten, który oferuje dziecku natura, tj. nieświadomy rozwój jego zdolności i popędów, któremu powinny zostać podporządkowane wszelkie inne oddziaływania i wpływy. Wychowanek powinien być uczniem natury, a nie ludzi - ma się uczyć przez własne doświadczenie i własną działalność. Rousseau akcentuje przy tym nie tylko wagę doświadczenia jako takiego, lecz również fakt, iż każdy człowiek posiada właściwy tylko sobie charakter, który decyduje o tym, w jaki sposób należy z nim postępować. Uwaga ta

\footnotetext{
3 [Książka ta przez badaczy twórczości Rousseau była często bagatelizowana jako wykład jego poglądów na temat wychowania. Tymczasem Alan Bloom we Wstępie do amerykańskiego wydania tej rozprawy stwierdza, iż uważać Emila za podręcznik wychowania oznacza brak (z)rozumienia tej książki. Dowodzi, że jest ona podręcznikiem wychowania w tym samym stopniu, co Państwo Platona. Emila przedstawia jako ważną lekturę filozoficzną, podkreślając, że jeśli jej celem jest wychowanie kogokolwiek, to jedynie przez zmianę postrzegania przezeń świata].
} 
stanowi dodatkowy argument na rzecz ostrożnego działania wychowawczego, poprzedzonego gruntownym poznaniem natury dziecka (Rousseau 1955: 4-5).

Rousseau równocześnie wskazywał, iż podstawowym zadaniem wychowawcy jest ochrona podopiecznego przed złymi wpływami otoczenia. Dzięki temu natura dziecka może swobodnie się rozwijać i nie zostanie wypaczona przez zgubny wpływ obyczajów i przesądów. Dlatego też wszelkie oddziaływanie wychowawcze powinno mieć charakter negacyjny - powinno polegać na usuwaniu wszelkich wpływów szkodliwych, nie zaś na bezpośrednim udzielaniu wychowankowi pozytywnych wskazówek.

Emil odsłania również progresywną wartość wychowania. Jak sądził Rousseau, każdy okres w życiu człowieka posiada właściwy sobie charakter oraz właściwą sobie doskonałość. Każdy też sam w sobie ma unikatową wartość. Z tej też przyczyny żaden okres życia (w tym także wiek dziecięcy) nie może służyć jedynie jako środek przygotowawczy w stosunku do następnego (Kot 1996: 13). Ze względu na zawartą w tym traktacie myśl, że wiek dziecięcy należy uważać za samodzielną „dobę” życia, a nie tylko za przygotowanie do dorosłości, Emil doczekał się nawet miana ewangelii dziecięctwa (Höffding 1900: 68).

Głównym celem wychowania Rousseau uczynił jednostkę samodzielną i niezależną od wpływów zewnętrznych. Był przekonany, że istnieje coś w rodzaju naturalnej drogi służącej rozwojowi i nauce człowieka, a edukacja powinna ułatwiać te procesy. Jego myśl wychowawcza opiera się na kilku ważnych zasadach: buncie przeciwko autorytetom, izolacji jednostki od kultury, niezależności jednostki, nacisku położonym na zdrowie i sprawność fizyczną wychowanka, nauczaniu związanym z wychowaniem przez zabawę, obserwacji, ćwiczeniach oraz miłości ku istocie własnej (Książek-Szczepanikowa, Kędzia-Klebko 2002: 143).

Rousseau wyjaśniał, że psychika dziecka jest różna od psychiki dorosłego, zaś jego rozwój przechodzi przez kilka etapów, z których każdy wymaga odrębnego traktowania i odmiennych zabiegów wychowawczych. Pierwsze dwa okresy (niemowlęctwo i dzieciństwo) (Rousseau 1955: 17, 20; 75-78) traktował jako etapy, które mają ograniczyć się do rozwijania zdrowia i zmysłów Emila, trzeci (chłopięctwo) - miał mu zapewnić (wy) kształcenie umysłu, czwarty zaś (wiek młodzieńczy) dedykowany był jego wychowaniu moralnemu.

\footnotetext{
${ }^{4}$ [Niemowlęctwo trwa do momentu opanowania przez dziecko mowy. Ta część traktatu poświęcona jest higienie i warunkom, w jakich żyje niemowlę czy karmieniu piersią. Rousseau wytyka rodzicom np. zbyt ciasne wiązanie becików; krytykuje matki, które oddają swoje dzieci mamkom na wychowanie i karmienie, zamiast karmić je własnym mlekiem itp. Celem dzieciństwa trwającego do 12 r.ż. jest, ukształtowanie „pełnego dziecka” (l 'enfant fait); nie zaś jego przygotowanie do dorosłości. Podstawowym zadaniem jest rozwijanie i wzmacnianie zdrowia dziecka i jego zmysłów. Do 12 r.ż. nie musi ono umieć czytać, nie chodzi też do szkoły. Jest to okres kształtowania bezpośredniego kontaktu dziecka ze światem zewnętrznym. Stopniowo i wszechstronnie zapoznaje się ono z rzeczywistością, uczy się zachowania równowagi między własnymi pragnieniami a możliwościami ich zaspokojenia oraz trafnej oceny tego, co ma. Dzięki temu staje się ono coraz bardziej odporne na przeciwności losu, cierpienia i braki. Nad wszystkim tym czuwa wychowawca. Na tym gruncie rozpoczyna się naturalne wychowanie moralne, dzięki któremu dziecko stanie się ,człowiekiem mocnym” (który zadowala się tym, czym jest i tym, co ma) i kiedy uświadomi sobie ono, iż to, czym jest i to, co ma pozostaje w zgodzie z jego naturą].
} 
Głównym zadaniem etapu chłopięctwa (które trwa mniej więcej od 12. do 16. r.ż.) jest utrzymanie chłopca w dobrym zdrowiu, wyrobienie u niego sprawności fizycznej i jego ochrona przed „złymi namiętnościami” płynącymi ze świata. Wychowanie ma uczynić go osobą szczęśliwą i wolną. Dopiero na tym etapie rozwojowym Rousseau zaleca rozpoczęcie kształtowania umysłu Emila przez naukę; ta jednak powinna mieć charakter bardziej praktyczny niż teoretyczny. Wychowawca powinien zatem dbać o to, by jego podopieczny poznawał praktyczne rozwiązania wypływające z „suchej” nauki i prowadzić go ku zdobyciu zawodu w jakimś rzemiośle (Emil, jak pamiętamy, zostaje stolarzem). Rousseau pisał: „Sto razy wolę, aby dziecko niczego się nie uczyło, niż gdyby się czego uczyło z ambicji lub próżności. Bezpośrednia użyteczność to najpewniejsza sprężyna nauki: oto święte słowo określające wszystkie czynności Emila” (tamże: 217). Co ciekawe, lekturą polecaną wychowankowi w tym czasie jest Robinson Cruzoe, czyli opowieść o samotniczej, niezależnej egzystencji zbliżonej do stanu natury, w którym żył „szlachetny dzikus” (tamże: 225-226).

Po etapie chłopięctwa następuje młodzieńczość, która trwa do około 20. roku życia. Rousseau poświęca jej najobszerniejszy rozdział traktatu. Do tego czasu kształtowano u wychowanka działanie i myślenie. Wiek młodzieńczy jest w przekonaniu Rousseau tym okresem życia młodego człowieka, w którym następuje pora na rozwój uczuć i wychowanie moralne. Jest to także odpowiedni moment na uświadomienie Emilowi istnienia Boga i nieśmiertelności duszy jako środków służących zachowaniu czystości moralnej (Rousseau 1955: 76 i n.). W tym też okresie młodzieniec powinien nabywać wiadomości historyczne i literackie, uczyć się języków obcych, podróżować, a także uczęszczać do teatru, aby mógł wyrobić sobie ,estetyczny smak (tamże: 5-218).

Dorosłość analizuje i omawia Rousseau w przedostatniej księdze traktatu o wychowaniu. W rozdziale tym filozof pokazuje swoistą cykliczność tego procesu. Wychowanie Emila bowiem kończy się dopiero w momencie, gdy zostaje on ojcem. Otwiera to nowy cykl wychowania. Aby dzieci Emila były wychowane równie dobrze jak on, niezbędna jest dobra współtowarzyszka życia. Księga piąta traktatu poświęcona jest zatem Zofii - wybrance Emila. Zanim ją pozna, jest zdrowym i silnym młodzieńcem, którego cechuje: samodzielność, życzliwość, dobroć serca, nieobojętność na krzywdę innych, skromność, chęć podobania się kobietom, dobry gust i smak, pracowitość i aktywne życie. Wychowanie Emila zmierza ku temu, by pokochał skromną Zofię (tamże: 219-402). Zadaniem Zofii jest zostać dobrą żoną i matką, dlatego jej wychowanie jest głównie ukierunkowane na realizację tych właśnie zadań, co Rousseau postrzega jako zgodne z naturą kobiety (tamże: 230)․

\footnotetext{
[Rousseau wyklucza równość płci, zalecając akceptację natury kobiety i mężczyzny, które postrzega przez pryzmat funkcji biologicznych. Kobiecość łączy ze zdolnością do rodzenia, jako podstawową funkcją biologiczną. Zofia ma być czysta moralnie, uczciwa, wierna i zależna od mężczyzny, religijna; zalety jej umysłu pozostają zdecydowanie na „drugim planie”. Chociaż Rousseau pisze: „(n)atura życzy sobie, aby kobiety sądziły i myślały, aby lubiły i umiały dbać o swój umysł nie mniej, niż dbają o wygląd zewnętrzny. Zarówno bowiem umysł, jak i wygląd stanowią broń, jaką natura włożyła w ręce kobiety dla zrównoważenia męskiej siły i dla rządzenia nami”, jednak wypowiedź tę odebrać należy raczej jako
} 
Swoimi poglądami Rousseau dokonał zasadniczego przewrotu w naukach o wychowaniu i jego praktyce. Głoszone przez niego poglądy przyczyniły się do rozwoju ówczesnej (i późniejszej) idei dzieciństwa, podkreślając jego wagę jako wartości samej w sobie, która niesie niepowtarzalne możliwości istnienia. Emil sprawił, że dziecku po raz pierwszy zaczęto przyznawać wartość samoistną, dzięki czemu po wiekach nieobecności w kulturze europejskiej stało się ono jej immanentną częścią. Sprawiło to, że w wychowaniu zaczęły się zmieniać dotychczasowe akcenty i proporcje. Zapoczątkowane przez niego myślenie sprawiło w końcu, że w centrum zabiegów edukacyjnych usytuowano dziecko, nie zaś program nauczania/wychowania czy nauczyciela. Dostrzeżono nieodzowność wdrażania wychowanków do samodzielnego myślenia i działania oraz potrzebę równoczesnego rozwijania ciała, umysłu i charakteru dziecka. Zaczęto zwracać uwagę na miejsce i rolę wolności, uczuć i uczuciowości człowieka (w tym także dziecka) w procesach edukacyjnych. Równocześnie jednak porównując wychowanie Zofii z wychowaniem Emila, należy zaznaczyć, że wszystkie te nowatorskie zasady zapoczątkowały zmiany w myśleniu o edukacji chłopców. Wychowanie dziewcząt przez długie lata pozostawało nadal zgodne z „kanonem” epoki jako przystosowane do potrzeb życia rodzinnego i społecznego.

Koncepcje pedagogiczne Rousseau cieszyły się w Europie dużą popularnością - należy przy tym pamiętać, że uruchomiły one nie tylko głosy aprobaty, lecz również krytykę, wzbudzając liczne polemiki. Jednym z najbardziej zagorzałych polemistów Rousseau był Helvétius, który jako „klasyk” pedagogiki wytoczył przeciwko Szwajcarowi i jego koncepcji wychowawczej jeden z najcięższych zarzutów, a mianowicie ten, że Rousseau był piewcą nieuctwa (por.: Helvétius 1976).

\section{Myśl J.J. Rousseau a dziecięce filozofowanie}

Nasze dzieciństwo jest jedyna niezniekształcona forma natury, która spotyka się jeszcze wśród cywilizowanej ludzkoścí ${ }^{6}$.

F. Schiller

Zastanówmy się, czy w zrekonstruowanej wyżej przestrzeni naturalnej edukacji Emila jest miejsce dla dziecięcego filozofowania? Pomimo niewątpliwych zasług Rousseau w postrzeganiu dzieciństwa, jego teksty dostarczają na to pytanie odpowiedzi pesymistycznej, która ma swoją podstawę w tym, jak filozof ten postrzegał poznawcze możliwości dziecka, kulturę i jej wpływ na dziecko oraz samą filozofię (jako immanentny element kultury).

Próba usytuowania dziecięcego filozofowania na planie myśli J.J. Rousseau wymaga na początek uściślenia terminu dziecięce filozofowanie, co jest możliwe dzięki zakreśleniu pola znaczeniowego trzech krzyżujących się par opozycji dotyczących filozofii: ezoteryka

fasadową deklarację, niż szczerą pochwałę kobiecego rozumu, która znajduje przełożenia na ich edukację. Tak czy inaczej, Zofia nie może być dla Emila partnerem w dyskusji].

${ }^{6}$ Cyt. za: Freese H.-L. (2008), Nasze dzieci sa filozofami. Jak rozmawiać z dziećmi o poważnych sprawach. Kraków, Wydawnictwo WAM, s. 34. 
versus egzoteryka filozofii; filozofia jako nauka versus filozofia jako oświecenie (por.: Martens, Schnädelbach 1995: 33-56) oraz filozofowanie profesjonalne versus filozofowanie nieprofesjonalne (Szczepska-Pustkowska M. 2011: 101-105). Kluczowe kategorie wspomnianych opozycji pozwalają na zgrubne zakreślenie dwóch wizerunków filozofii.

Pierwszy z nich ukazuje ją jako wiedzę o charakterze ezoterycznym (tzw. filozofię ekspertów, dostępną jedynie wąskiemu, elitarnemu gronu), jako system wiedzy cechującej się logiczną doskonałością (istotnym warunkiem jej zaistnienia jest argumentacyjny refleksyjny potencjał tradycji filozoficznej; filozofowanie nie jest możliwe bez takiego wykształcenia, które wyposaża człowieka w kulturowe techniki czytania znaczeń oraz które pozwala zdobyć wprawę w interpretowaniu i w racjonalnym dyskursie) oraz jako naukę zorientowaną przedmiotowo, która pozwala na poznawanie prawdy i wiedzy ważnej intersubiektywnie. Tak rozumiana filozofia wymaga namysłu wpisanego w swoją dziejowość i zakorzenionego w myśleniu innych filozofów, w którym mamy do czynienia z refleksją charakteryzującą się autotelicznością, ezotercznością, samodzielnością/osobistością, dialogicznością, całościowym spojrzeniem oraz dwukierunkowością nastawienia (tj. przyjmowaniem za przedmiot refleksji zarówno rzeczywistości, jak i samej refleksji nad nią). Ten rodzaj filozofowania można określić mianem profesjonalnego (Pobojewska 2001: 29-31; Szczepska-Pustkowska 2011: 101-105).

Dla tak rozumianej filozofii w edukacji Emila nie ma oczywiście miejsca już choćby z tej racji, że pozostaje ona $\mathrm{w}$ jawnej sprzeczności z naturą dziecka. Myśl Rousseau bowiem ogarniająca całość wychowania dziecka, w tym także jego życie intelektualne nakazywała, by dzieciństwo i jego właściwości postrzegać jako stan, w którym człowiek pozostaje najbliżej natury i zalecała, by chronić go możliwie jak najdłużej przed duszącymi, chorymi wydzielinami cywilizacji, w tym także przed filozofią (Postman 2001:133).

Rousseau rozwija tę myśl zgodnie z duchem romantyzmu i porównuje dziecko do dzikiej rośliny, której rozwój ma charakter organiczny i naturalny i która dla prawidłowego wzrostu i rozwoju wymaga jedynie odpowiedniej pielęgnacji. Do matek zwraca się więc tymi słowy: „(u)prawiaj, podlewaj młodą latorośl, żeby nie zamarła; jej owoce będą ci kiedyś rozkoszą. Otaczaj zawczasu wałem ochronnym duszę swego dziecka; ktoś inny może zakreślić jego obwód; ale ty jedna winnaś wznieść ogrodzenie. Rośliny kształtuje uprawa, ludzi wychowanie" (Rousseau 1955: 8).

Podkreślał, że podczas gdy natura wychowuje powoli, ludzie zwykle zbytnio się śpieszą. Dlatego też jedna z najważniejszych wskazówek, jakiej udzielał wychowawcom powiada, iż umiejętna „uprawa” duchowa polega na możliwym powstrzymywaniu od rozwoju. Na tym tle Rousseau wchodzi nawet w polemikę z ideami głoszonymi przez Johna Locke`a. O ile ten bowiem sadził, iż należy jak najwięcej z dzieckiem dyskutować i dostarczać mu „materiału” do (prze)myślenia, by dzięki temu stawało się ono coraz bardziej rozumne, o tyle Rousseau ogranicza kontakt dziecka ze światem jedynie do rzeczy (,utrzymuj dziecko w zależności od rzeczy jedynie, a będziesz posłuszny rozkazowi natury w postępie jego wychowania") (tamże: XXXVI). Dowodzi, że rozum rozwija się dopiero wtedy, gdy rozwinęły się już inne władze. Wychowanie człowieka rozumnego traktuje 
jako cel odległy, bo rozciągnięty w czasie. Zarzuca koncepcjom Locke 'a, że uznając człowieka z góry jako istotę rozumną, zaczyna rzecz od końca. Traktuje bowiem dzieło, które pragnie wytworzyć, jako narzędzie, przy pomocy którego ma ono zostać wytworzone. Dowodzi, że wyobrażenia człowieka (które mają charakter zewnętrzny) powstają z uczuć (które w przeciwieństwie do nich posiadają charakter wewnętrzny). Dlatego też to właśnie uczucia powinny wieść prym w wychowaniu dziecka, nie zaś odwrotnie. Człowiek przyswaja sobie jedynie to, co budzi w nim zainteresowanie; to zaś zależy od stopnia rozwoju jednostki (tamże: 84-85).

Podczas gdy dla Johna Locke'a edukacja oznaczała proces „dodawania” kolejnych wartości do niezapisanej karty, do której metaforycznie porównywał dziecko i wzbogacania jej o kolejne treści, dla Rousseau proces ten wiązał się z odejmowaniem tych wartości, w które natura wyposażyła dziecko. Zbyt wczesny kontakt dziecka z cywilizacją i kulturą w jakiejkolwiek formie sprawiał - jego zdaniem - że ubywa mu wartościowych cech, w które z natury jest ono wyposażone. Edukacja niszczy w nim zatem to, czym obdarzyła je natura - prawdę, dobro i piękno. Dziecko wyposażone od urodzenia w takie cechy, jak szczerość, ciekawość i spontaniczność, lecz niewystarczająco dojrzałe, psute jest przez naukę czytania i pisania oraz inne formy oddziaływań edukacyjnych. Chroniąc je tak długo, jak to możliwe przed edukacją, chronimy je równocześnie przed niebezpieczeństwami, które oddalają je od jego prawdziwej istoty. Dla dobra dziecka należy więc jak najdłużej strzec je przed wyobcowanym i zracjonalizowanym światem dorosłych, w tym także przed filozofowaniem, pozwalając mu oddawać się domenom dlań bardziej odpowiednim - zabawie oraz fantazji. Chroniąc Emila przed chorymi wydzielinami cywilizacji, Rousseau zaleca nawet, by ułatwić mu życiodajną bliskość z naturą. Proponuje, by ten wzrastał w środowisku wsi - pod wieloma względami bliższej pożądanemu stanowi naturalnemu niż miasto. Pomysł ten poddaje krytyce Helvétius, pytając dlaczego żyjący w naturze człowiek nieokrzesany miałby być lepszy od oświeconego mieszkańca miasta (Helvétius 1976: 273).

Na kartach Emila odnajdujemy nawet swoisty „,manifest”, w którym Rousseau pisze: „(p)rzyroda chce, żeby dzieci były dziećmi, zanim będą ludźmi. Jeżeli chcemy odwrócić ten porządek, wytworzymy owoce przedwczesne, które nie będą miały ani dojrzałości, ani smaku i zepsują się w krótkim czasie; będziemy mieli młodych uczonych i stare dzieci. Dzieciństwo zna właściwe sobie sposoby widzenia, myślenia, czucie; nie ma nic błędniejszego, niż chcieć je zastąpić sposobami właściwymi ludziom dorosłym; mógłbym z równą słusznością żądać, żeby dziecko miało pięć stóp wysokości, jak tego, by miało rozsądek w dziesiątym roku życia. W istocie, na cóż by mu się zdał rozum w tym wieku? Rozum jest wędzidłem siły, a dziecku to wędzidło jest niepotrzebne" (tamże).

Chociaż zatem Rousseau akcentuje wagę wolności oraz samodzielnego myślenia i działania dziecka, to równocześnie wskazuje, że w wieku dziecięcym są one nieosiągalne. Jeśli jednak pojawią się wbrew naturze dziecka, nie posiadają istotnej wartości ani dla samego wychowanka, ani dla społeczności, w której on wzrasta. Rousseau poddaje w wątpliwość ich dojrzałość i wartość merytoryczną; wyraża wreszcie obawę, że w rezul- 
tacie staną się przyczyną zepsucia. W edukacji Emila, podporządkowanej naturze, czas na aktywność intelektualną przychodzi dopiero we wczesnej dorosłości, bo nawet jako młodzieniec przygotowuje się on dopiero do wysiłku intelektualnego ogarniania świata.

Niewyartykułowany podtekst, jaki towarzyszy przywołanej myśli Rousseau, prowadzi, jak się wydaje, do kolejnych zasad wychowania, które nakazują pozostawić dziecko w stanie natury tak długo, jak to możliwe. Rousseau uzasadnia to stwierdzeniem, iż nie zna człowieka, który nie nauczyłby się chodzić, mimo że go tego nie uczono; w tym zakresie działa bowiem sama natura. Człowiek nie powinien więc ani wyręczać, ani też przyspieszać działania natury, która jest najlepszym nauczycielem. To zapewne z tej przyczyny do edukacji w wieku dziecięcym i chłopięcym filozof podchodzi minimalistycznie, wskazując, że podstawową zasadą edukacji w tym okresie powinno być możliwe powstrzymywanie rozwoju intelektualnego i duchowego dziecka.

Wielu myślicieli i badaczy przed Rousseau i po nim także zdecydowanie odmawiało dzieciom zdolności do filozoficznego oswajania świata i zalecało, by trzymać je z daleka od filozofii. Choć byli też tacy, którzy relację tę (pod postacią metafizycznych praprzeżyć z dzieciństwa czy pytań formułowanych w tym okresie) uważali za istotne źródło inspiracji i problemów dla filozofii jako takiej. Nie oznaczało to jednak, że dziecko ma jakiekolwiek „prawo” do filozofii czy filozofowania, które traktowane były jako domena dorosłych (tamże).

Nic też dziwnego, że współczesny sceptycyzm wobec dziecięcego filozofowania czy filozofowania z dziećmi bywa wzmacniany argumentacją zaczerpniętą właśnie z myśli J.J. Rousseau, która wskazuje, że filozofia jest dzieciom niedostępna tak ze względu na naturę dziecka, jak i złożoną naturę samej filozofii. Przyjęte tu bezdyskusyjnie argumenty antropologiczne, socjokulturowe i filozoficzne (Martens 1996: 41-43) ${ }^{7}$, dopełnia się współczesnymi zarzutami natury psychologiczno-rozwojowej. Te zaś wskazują, że jako ciągły systematyczny namysł nad światem filozofowanie wymaga operacji myślenia formalnego (lub metakognitywnego), które pojawia się w rozwoju dziecka dopiero między 11. a 14. rokiem życia. Dowodzi tego powszechnie uznana teoria rozwoju J. Piageta (Kit-

7 [Przeciwko możliwości dziecięcego filozofowania i filozofowania z dziećmi podnoszone bywają zarzuty trojakiego rodzaju: filozoficzne, pedagogiczne oraz psychologiczno-rozwojowe. Wśród zarzutów natury filozoficznej są argumenty dotyczące dziecięcych uzdolnień, natury dziecka, oraz złożoności samej filozofii). Dwa pierwsze argumenty wskazują, że do zajmowania się filozofią potrzebne są specjalne „uzdolnienia filozoficzne”, których nie można się nauczyć. Są one „darem łaski”, który nie każdemu jest dany. Zbyt wcześnie rozpoczynane filozofowanie z dziećmi ogranicza naturalny rozwój ich wolności. Pojawia się tu również argument wskazujący, że filozofia i filozofowanie są czymś odległym dziecku i dzieciństwu. Postrzegane jako dyscypliny elitarne, do uprawiania których potrzebne są wyjątkowe predyspozycje intelektualne, jawią się jako przestrzeń zamknięta dla jeszcze „,niegotowych” (intelektualnie) i ,niepełnoletnich”, jak to określał Kant, dzieci (a i nie dla wszystkich dorosłych otwarta). Krótko mówiąc - filozofia postrzegana jako refleksyjna racjonalność, systematyczne myślenie zorientowane na pryncypia lub myślenie metateoretyczne przerasta zdolności dzieci - i nie tylko dzieci. Zakłada ona bowiem poziom, „na którym ma się już za sobą kilka kroków wprowadzenia w naukową kulturę”" (tj. historyczne dziedzictwo, obiektywną naukę i uznane normy). W przypadku dzieci właśnie owo „wprowadzenie” i „refleksyjna racjonalność" - jak uważają niektórzy - nie są możliwe]. 
chener 1990: 416-431), która nadaje ideom Rousseau dodatkową moc weryfikowalności naukowej.

\section{Barba non facit philósophum, czyli parę słów zakończenia}

Omówione wyżej podejście, które wyklucza dziecięce filozofowanie z granic edukacji zakreślonej przez myśl J.J. Rousseau, można dopełnić innym - bardziej optymistycznym, choć zdecydowanie wykraczającym poza tę myśl. Wymaga to sięgnięcia po drugi wizerunek filozofii (i filozofowania) oraz zastanowienia nad pytaniem, czy w zrekonstruowanej przestrzeni naturalnej edukacji Emila znalazło by się miejsce dla dziecięcego filozofowania, gdyby filozofia (i filozofowanie) zostały określone z użyciem kategorii egzoteryka, oświecenie i filozofowanie nieprofesjonalne, obecnych w polu znaczeniowym przywołanych wcześniej krzyżujących się par opozycji dotyczących filozofii.

Jeśli bowiem filozofię uznać za wiedzę o charakterze egzoterycznym (powszechnie dostępną - filozofię laików), która oznacza umiejętność praktyczną (dotyczącą autonomii działania i etyczności, które są dostępne i możliwe dla każdego człowieka, również bez wsparcia filozofii) oraz jako oświecenie zorientowane podmiotowo, na analizujące, interpretujące i rozpoznające zajmowanie się osoby filozofującej samą sobą, to zyskujemy odmienną optykę oglądu fenomenu dziecięcego filozofowania. Charakteryzuje je przewaga egzoteryki (oczekiwań dotyczących umiejętności filozofowania formułowanych względem filozofii spoza jej granic) oraz przewaga filozofii rozumianej jako oświecenie, akcentującej znaczenie filozofującego podmiotu. Dziecko ze swoim sposobem pytania i sądzenia o świecie, mieści się ponadto w przestrzeni filozofowania nieprofesjonalnego, które pozostaje myśleniem nieświadomym całej filozoficznej tradycji i właściwości (Szczepska-Pustkowska 2011: 101-105).

Dzięki tak rozłożonym akcentom większe znaczenie zyskuje kształtowanie umiejętności i postaw filozofującego podmiotu, niż zdobywanie przezeń wiedzy. W ten oto sposób filozofia może zostać określona mianem sztuki myślenia ${ }^{8}$. Użyte określenia, podkreślają głównie umiejętnościowo - podmiotowy aspekt filozofowania. Nie chodzi zatem o studiowanie przez dzieci/ z dziećmi życiorysów i poglądów poszczególnych filozofów czy historii i ewolucji poszczególnych doktryn i nurtów filozoficznych, lecz o kształtowanie umiejętności krytycznego i twórczego myślenia oraz wspieranie dziecięcej autorefleksyjności i samorozwoju. Na tak rozumianą filozofię i filozofowanie, jak sądzę, można by znaleźć miejsce w teorii edukacji Rousseau, który cenił wolność, samodzielność i ory-

\footnotetext{
8 J. Spychała, Dlaczego dzieci sa filozofami, http://www.polityka.pl/tygodnikpolityka/nauka/217656,1,dlaczego-dzieci-sa-filozofami.read [dostęp: 8.04.2015]. [Wszak traktowanie filozofii jako „sztuki dla sztuki” (której uprawianie stanowi jakoby wartość samą w sobie) jest najlepszym świadectwem jej nierozumienia (może nawet zaprzeczeniem jej ducha). Filozofia w swych początkach, jak zauważa J. Spychała, była na wskroś praktyczna. „Służyła odpowiedzi na pytanie: jaki jest świat? i w związku z tym: jak żyć należy - jak żyć, aby osiągnąc szczęście, aby nie krzywdzić innych i samemu krzywdy nie doznawać? Ale o tym zapomniano"].
} 
ginalność myślenia, rodzącą się indywidualność dziecka (por. Sztobryn 2009: 43-55)9 , choć sam filozof nigdzie możliwości takiej wyraźnie nie wskazuje ${ }^{10}$. Pisze co prawda: „Powiadają, że wiele akuszerek uważa, jakoby ugniatając głowę dziecka nadawały jej właściwy kształt; i pozwala się na to! Głowy nasze miałyby więc być źle ukształtowane przez Stwórcę: trzeba by były ukształtowane z zewnątrz przez akuszerki, a z wewnątrz przez filozofów" (Rousseau 1955: 17). Jednak intencja tego stwierdzenia nie prowadzi wcale do pochwały filozofii (jako wartości w edukacji dziecka), lecz raczej do krytyki „niewolniczych” przesądów, obyczajów, praktyk wszelkiego rodzaju przymusu i ucisku, które stosuje się w wychowaniu wobec najmłodszych.

Myśl, że filozofia i filozofowanie może stać się udziałem dzieci posiada jednak historię znacznie dłuższą niż historia idei J.J. Rousseau. Łacińskie przysłowie Nie broda czyni filozofa wskazuje, że przepustką do myślenia filozoficznego i filozofii jest nie tylko wiek (dojrzały). Stanowiska takiego bronili ci myśliciele różnych epok, którzy filozofię uznawali co najmniej za swoistą instrukcję i wprowadzenie dzieci do moralnego życia, godnego umierania oraz jako nieoceniony trening duchowy (tamże: 111-112).

Również wielu współczesnych badaczy zafascynowanych światem dziecięcych przeżyć i doświadczeń, przedmiotem swoich studiów uczyniło dziecięce zdziwienia, fenomen dziecięcych pytań i zapytywania (Lipman, Sharp, Oscanyan 1996: 47) ${ }^{11}$. Studiują go i poddają namysłowi filozofowie i psychologowie; coraz więcej miejsca poświęca tym zagadnieniom pedagogika koncentrująca swoje studia na dzieciństwie rozumianym jako

\footnotetext{
9 [Pamiętając o tym, że w ujęciu J.J. Rousseau zarówno wolność jako wartość jest człowiekowi immanentnie dana (jesteśmy zatem z natury wolni), należy równocześnie pamiętać, że wbrew przeświadczeniom Rousseau - człowiek najmniej wolny jest w dzieciństwie, a rzeczywistą wolność uznaje się raczej za wartość właściwą duchowi dojrzałemu, świadomemu, kreatywnemu i zdolnemu do idealizacji. Zachowanie pełnej i nieskrępowanej niczym wolności możliwe jest jedynie dzięki wychowaniu negatywnemu, które Rousseau wyjaśniał jako powstrzymanie się od wychowania. Na dodatek wolność w tym ujęciu ma charakter statyczny (posiada się ją lub jest się wolnym). S. Sztobryn zwraca uwagę na pytanie o kryterium, na podstawie którego możemy mówić, że ktoś ma wolność bycia wolnym czyli prawo do wolności lub nie. Przypomina, że rousseusowka teza, iż człowiek rodzi się wolny nie została naukowo potwierdzona; Immanuel Kant udowodnił nawet słabość tego rozstrzygnięcia].

${ }^{10}$ Por.: J. Spychała, Dlaczego dzieci sa ..., op. cit. [Wszelkie świadectwa wskazują, że Rousseau nie podjął nawet próby wychowywania swojego licznego potomstwa, podrzucając je pod drzwi klasztorów. Jego obrony (sprzecznej zresztą z duchem antycznej filozofii) podjął się wiele lat później Max Scheler mówiąc, że filozof jest jak drogowskaz - drogowskaz drogę wskazuje, ale sam nią nie chodzi. Tymczasem „filozofowie nie tylko uczyli, jak żyć, ale sami starali się żyć, jak uczyli, i to stanowiło miarę ich wiarygodności - to czyniło z nich filozofów"].

${ }^{11}$ [Dostrzeżono, że filozoficzne myślenie dzieci (podobnie jak myślenie filozoficzne w ogóle) swój początek czerpie z fenomenu zdziwienia, wątpliwości i ciekawości - głębokiej i radosnej. Dzieci dziwią się, a ich zdziwienie przybiera kształt dociekliwego zapytania i od tej chwili zaczynają myśleć filozoficznie, poszukując odpowiedzi. Dzisiejsza wiedza o dziecku pozwala również rozumieć dziecięce zajmowanie się filozofią jako naturalną skłonność dzieci do zadawania pytań (filozoficznych) wynikającą ze zdziwienia światem czy też jako filozofowanie w obrębie wspólnoty dociekającej, jaką może być przykładowo klasa szkolna. (Współ)dociekanie z dziećmi w klasie (traktowane jako alternatywna metoda pracy z uczniem) wykorzystuje właśnie tę naturalną skłonność dziecka zapytywania o świat].
} 
dziecięcy świat przeżywany (por. Szczepska-Pustkowska 2011). Wielu badaczy, analizując ów fenomen z perspektywy własnej dyscypliny i dostrzegając różne jego aspekty, zgadza się co do tego, że w dziecięcych próbach zmagania ze światem spotykają się i splatają „,zapotrzebowanie” na filozofowanie i „możliwości/zdolności” do podejmowania wysiłku filozofowania przez najmłodszych (Freese 2008: 41-42; Szczepska-Pustkowska 2011: 101-105).

H-L. Freese powiada, że „,w przebiegu rozwoju intelektualnego każdego dziecka nieunikniony jest moment, kiedy tworząc sobie swój obraz świata, trafia ono na <pytania ostateczne>"12. Sven G. Hartman, szwedzki badacz dzieciństwa zauważa, że pytania formułowane przez dzieci mają charakter egzystencjalny, dotyczą bowiem fundamentalnych warunków ludzkiego życia i egzystencji jako takich. Chociaż forma, jaką przyjmują, bywa różna, jednak zawsze są one wyrazem osobistej/indywidualnej potrzeby strukturyzacji i restrukturyzacji czyjegoś sposobu doświadczania otoczenia i egzystencji w szerokim ich sensie. Są także świadectwem wysiłku podejmowanego przez dziecko w celu zinterpretowania i zrozumienia życia (Hartmana 1986: 20). Egzystencjalne pytania dzieci oraz wyrastający z nich osobisty obraz świata składają się na całość, którą określa jako dziecięcą filozofię życia (tamże).

Pytając o egzystencję, jak zauważa Léon-Louis Grateloup, człowiek wkracza w samo sedno wszelkich pytań filozoficznych (Grateloup 2004: 30). Spostrzeżenie to dotyczy także dzieci, które formułują (za)pytania wątpiąc, dokonując refleksji nad sobą i własnym losem, a ich życiu towarzyszy pragnienie odnalezienia i (z)rozumienia sensu własnej egzystencji oraz pragnienie kierowania nią. W ten sposób zapytujące filozoficznie dzieci często wkraczają w przestrzeń namysłu filozoficznego i bywa, że poszukując własnych rozumień świata, odtwarzają idee i tok myślenia „wielkich” filozofów.

\section{Literatura}

Bloom A. (1979), Introduction. [W:] J.J. Rousseau, Emil: or, on education. New York, Basic Books. Branowska M. (2013), Marzenie o szczęściu, czyli idea prawa natury w filozofii Jana Jakuba Rousseau, „Czasopismo Prawno-Historyczne” Tom LXV, Zeszyt 2.

Freese H.-L. (2008), Nasze dzieci sa filozofami. Jak rozmawiać z dziećmi o poważnych sprawach. Kraków, Wydawnictwo WAM.

Freese H.-L. (2012), Filozofia dla dzieci?, http://www.deon.plhttp://www.deon.pl/inteligentne-zycie/wychowanie-dziecka/art,444,filozofia-dla-dzieci.html [dostęp: 4.03.2015].

Golka M. (2012), Cywilizacja współczesna i globalne problemy. Warszawa, Oficyna Naukowa.

Grateloup L.-L. (2004), Wędrówki po filozofii. Wrocław, Siedmioróg.

Hartman S.G. (1986), Childrens philosophy of life. Stockholm, Stockholm Institute of Education, Department of Educational Research.

Helvétius C.A. (1976), O człowieku, jego zdolnościach umysłowych i wychowaniu. Wrocław, Ossolineum.

${ }^{12}$ Freese H.-L. (2012), Filozofia dla dzieci? http:// www.deon.plhttp://www.deon.pl/inteligentne-zycie/ wychowanie-dziecka/art,444,filozofia-dla-dzieci.html [dostęp: 4.03.2015]. 
Höffding H. (1900), Jan Jakób Rousseau. Życie i dzieła. Warszawa, Bronisław Natanson. Jẹdraszko Cz. (1968), Łacina na co dzień, Warszawa, NK.

Kitchener R.F. (1990), Do children think philosophically? "Methaphilosophy" October, Vol. 21, $\mathrm{Nr} 4$.

Klus-Stańska D. (2004), Światy dziecięcych znaczeń - poszukiwanie kontekstów teoretycznych. W: D. Klus-Stańska (red.), Światy dziecięcych znaczeń. Warszawa, Wydawnictwo Akademickie „Żak”.

Kot S. (1996), Historia wychowania. T. 2. Wychowanie nowoczesne. Od polowy XVIII wieku do wspótczesnej doby. Warszawa, Wydawnictwo Akademickie „Żak”.

Książek-Szczepanikowa A., Kędzia-Klebko B. (2002), Czytanie „Emila” J.J. Rousseau. Szczecin, Wydawnictwo Uniwersytetu Szczecińskiego.

Lipman M., Sharp A., Oscanyan F. (1996), Filozofia w szkole. Warszawa, Wydawnictwo CODN.

Martens E. (1996), Filozofowanie z dziećmi jako impuls (choć nie tylko) lekcji etyki. W: B. Elwich, A. Łagodzka (red.), Filozofia dla dzieci. Wybór artykułów, Warszawa, Fundacja Edukacja dla Demokracji.

Martens E., Schnädelbach H. (red.) (1995), Filozofia. Podstawowe pytania. Warszawa, Wiedza Powszechna.

Orłowski B. (1921), Krytyka wartości kultury u Rousseau i przed Rousseau. Poznań, Gebethner i Wolff.

Peretiatkowicz A. (1949), Jan Jakub Rousseau. Filozof demokracji społecznej. Księgarnia Zdzisława Gustowskiego.

Pobojewska A. (2001), Filozofowanie - nowy wymiar edukacji. W: D. Probucka, A. Olech, M. Woźniczka (red.), Pasja czy misja? O uczeniu filozofii. Częstochowa, Wydawnictwo WSP w Częstochowie.

Postman N. (2001), W stronę XVIII stulecia. Jak przeszłość może doskonalić nasza przyszłość. Warszawa, PIW.

Rousseau J.J. (1954), Rozprawa o pochodzeniu i podstawach nierówności między ludźmi. Warszawa, Wydawnictwo Naukowe PWN.

Rousseau J.J. (1955), Emil czyli o wychowaniu. Tom I. Wrocław, Zakład im. Ossolińskich - Wydawnictwo PAN.

Rousseau J. J. (1956), Rozprawa na temat: czy odrodzenie się nauk i sztuk przyczyniło się do naprawy obyczajów. W: tegoż, Trzy rozprawy z filozofii społecznej. Warszawa, Wydawnictwo Naukowe PWN.

Rousseau J.J. (2010), Umowa społeczna. Warszawa, Wydawnictwo Naukowe PWN.

Spychała J. (2007), Dlaczego dzieci sa filozofami, http://www.polityka.pl/tygodnikpolityka/nauka /217656,1,dlaczego-dzieci-sa-filozofami.read [dostęp: 8.04.2015].

Szczepska-Pustkowska M. (2004), Tropami dziecięcych pytań filozoficznych. W: D. Klus-Stańska (red.), Światy dziecięcych znaczeń. Warszawa, Wydawnictwo Akademickie „Żak”.

Szczepska-Pustkowska M. (2011), Od filozofii dzieciństwa do dziecięcej filozofii życia. Casus władzy i demokracji, Kraków, Oficyna Wydawnicza Impuls.

Sztobryn S. (2009), Jaka wolność taka edukacja. [W:] M. Zalewska-Pawlak (red.), Sztuka wobec zakresów wolności człowieka liberalnego. Pedagogiczne rozważania i doświadczenia. Łódź, Wydawnictwo Uniwersytetu Łódzkiego. 